Reselch

\title{
Angiotensin II and the JNK pathway mediate urotensin II expression in response to hypoxia in rat cardiomyocytes
}

\author{
Chiung-Zuan Chiu ${ }^{1,2}$, Bao-Wei Wang ${ }^{1}$ and Kou-Gi Shyu ${ }^{2,3}$ \\ ${ }^{1}$ School of Medicine, Fu-Jen Catholic University, New Taipei City 242, Taiwan, Republic of China \\ ${ }^{2}$ Division of Cardiology, Shin-Kong Wu Ho-Su Memorial Hospital, 95 Wen-Chang Road, Taipei 111, Taiwan, \\ Republic of China \\ ${ }^{3}$ College of Medicine, Graduate Institute of Clinical Medicine, Taipei Medical University, Taipei 110, Taiwan, \\ Republic of China
}

Correspondence should be addressed to K-G Shyu

Email

m004401@yahoo.com.tw

\begin{abstract}
Cardiomyocyte hypoxia causes cardiac hypertrophy through cardiac-restricted gene expression. Urotensin II (UII) cooperates with activating protein 1 (AP1) to regulate cardiomyocyte growth in response to myocardial injuries. Angiotensin II (Angll) stimulates UIl expression, reactive oxygen species (ROS) production, and cardiac hypertrophy. This study aimed to evaluate the expression of UII, ROS, and Angll as well as their genetic transcription after hypoxia treatment in neonatal cardiomyocytes. Cultured neonatal rat cardiomyocytes were subjected to hypoxia for different time periods. UII (Uts2) protein levels increased after $2.5 \%$ hypoxia for $4 \mathrm{~h}$ with earlier expression of Angll and ROS. Both hypoxia and exogenously added Angll or Dp44mT under normoxia stimulated UII expression, whereas Angll receptor blockers, JNK inhibitors (SP600125), JNK siRNA, or N-acetyl-L-cysteine (NAC) suppressed UII expression. The gel shift assay indicated that hypoxia induced an increase in DNA-protein binding between UII and AP1. The luciferase assay confirmed an increase in transcription activity of AP1 to the UII promoter under hypoxia. After hypoxia, an increase in ${ }^{3} \mathrm{H}$-proline incorporation in the cardiomyocytes and expression of myosin heavy chain protein, indicative of cardiomyocyte hypertrophy, were observed. In addition, hypoxia increased collagen I expression, which was inhibited by SP600125, NAC, and UII siRNA. In summary, hypoxia in cardiomyocytes increases UII and collagen I expression through the induction of Angll, ROS, and the JNK pathway causing cardiomyocyte hypertrophy and fibrosis.
\end{abstract}

Journal of Endocrinology (2014) 220, 233-246

\section{Introduction}

Cardiac hypertrophy and remodeling are considered to be compensatory processes in response to increased cardiac workload, caused by mechanical stress, hypertension, neurohumoral stimuli, myocardial injuries, or other environmental factors (Ni et al. 2006). After such events, the heart undergoes compensatory adaptation to maintain adequate circulation, which is regulated by cardiac-restricted genes. These adaptive changes include 
cardiac hypertrophy, proliferation of cardiac fibroblasts, and adjustment in the interstitial tissue. However, the persistence of these modifications may ultimately result in heart failure. Thus, cardiac hypertrophy is both a response to stress and an independent risk factor for cardiac morbidity and mortality.

Urotensin II (UII) has been identified as an endogenous peptide with a greater magnitude of vasoconstriction than endothelin 1 (ET-1), making UII the most potent mammalian vasoconstrictor (Ames et al. 1999). UII (Uts2) mRNA is widely expressed throughout the cardiovascular system (Papadopoulos et al. 2008, Tolle \& van der Giet 2008). UII has been shown to increase cardiac hypertrophy, cardiac fibrosis, and collagen synthesis both in vitro and in vivo (Zhu et al. 2006, Zhang et al. 2007). Reactive oxygen species (ROS) are involved in the UII-induced cardiomyocyte hypertrophy (Liu et al. 2009). One study has demonstrated that the generation of ROS is involved in UII-induced cell proliferation, tyrosine phosphorylation of epidermal growth factor receptors (EGFRs), and extracellular signal-regulated kinase (ERK) phosphorylation in rat cardiac fibroblasts (Chen et al. 2008). Moreover, it is now well established that UII levels are significantly increased in several cardiovascular diseases (Bousette \& Giaid 2006). Thus, UII may be an important determinant of cardiac dysfunction via additional nonhemodynamic effects on the myocardium, similar to angiotensin II (AngII) and ET-1 (Li et al. 2005). Specifically, Tzanidis et al. (2003) reported that UII stimulates collagen synthesis in cardiac fibroblasts, suggesting that UII may be involved in myocardial fibrogenesis. UII and its receptor (UII-R) are upregulated in patients with end-stage heart failure (Ng et al. 2002), ischemia (Pakala 2008), chronic hypoxia (MacLean et al. 2000), or post-myocardial infarct rat myocardium (Tzanidis et al. 2003). Upregulation of UII-R may worsen cardiac hypertrophy (Segain et al. 2007) and cardiac injury under ischemia-reperfusion (Prosser et al. 2008). The above findings suggest that UII may contribute to cardiovascular diseases through synergistic interactions with other vasoactive substances.

In response to hypoxia, the heart also generates ROS, resulting in cardiac hypertrophy and expression of fetal cardiac genes (Inamoto et al. 2006, Kontaraji et al. 2007, Yamashita et al. 2007) through various signaling cascades (Seta \& Millhorn 2004). A previous study has shown that the density of binding sites for UII in sarcolemma of the myocardium increased in rats exposed to chronic hypoxia (Zhang et al. 2002). Interestingly, UII-R upregulation in the myocardium of hypoxic rats was accompanied by ventricular hypertrophy (Huang et al. 2006). Hypoxia can also stimulate cardiomyocytes to secrete cytokines and growth factors (Inamoto et al. 2006). However, the effect of hypoxia on UII expression in cardiomyocytes is not yet fully understood. AngII has been shown to induce cardiac hypertrophy by increasing oxidative stress and UII expression (Lamarre \& Tallarida 2008). Earlier studies also indicated that AngII stimulated both UII expression and genetic transcription in cardiomyocytes to cause cardiac hypertrophy (Song et al. 2012). However, the expression of AngII and UII after hypoxia and the relationship between them in regulating genetic transcription in cardiomyocytes under hypoxia have not been well defined. Transcriptional regulation of UII-R by nuclear receptor- $\kappa \mathrm{B}$ and hypoxia-inducible factor- $1 \alpha$ has been reported (Segain et al. 2007, Gould et al. 2010). Moreover, the JNK pathway has been reported to mediate the oxidative stress induced by UII (Djordjevic et al. 2005). Our recent study documented that hypoxia-induced UII expression in cardiac fibroblasts is mediated by AngII and through the ROS and JNK pathways (Shyu et al. 2012). Thus, UII is a mediator of AngII-induced cardiac fibrosis under hypoxia.

This study was designed to investigate the molecular mechanisms and signal pathways mediating UII expression in cardiomyocytes under hypoxia and AngII stimulation. We hypothesized that activating protein 1 (AP1), a well-characterized downstream target of JNK, may play a role in the transcriptional regulation of UII. Our results indicated that, following hypoxia, cardiomyocyte hypertrophy, and cardiac-restricted gene expression were modulated in response to UII expression, specifically through the JNK pathway. AngII was expressed in response to hypoxia to enhance UII expression and cardiomyocyte gene transcription, as previously demonstrated in a cardiac fibroblast model. We also identified the signal transduction pathway that modulates these mechanisms after hypoxic injury.

\section{Materials and methods}

\section{Primary culture of left ventricular cardiomyocytes}

Cardiomyocytes were obtained from 2- to 3-day-old Wistar rats as described previously (Shyu et al. 2001). Cultured myocytes were $>95 \%$ pure as revealed by observation of contractile characteristics with a light microscope and were stained with anti-desmin antibody (Dako Cytomation, Glostrup, Denmark). The culture medium consisted of DMEM/F12 supplemented with $20 \%$ knockout serum replacement, $1 \%$ non-essential amino

Published by Bioscientifica Ltd. 
acids, $2 \mathrm{mM}$ L-glutamine, $0.1 \% \mathrm{~b}$-mercaptoethanol, and $0.1 \%$ of a commercially available penicillin/streptomycin stock solution (Invitrogen; $100 \mathrm{U} / \mathrm{ml}$ penicillin and $100 \mu \mathrm{g} / \mathrm{ml}$ streptomycin). The cells were transferred to serum-free medium (Ham's F-12-DMEM, 1:1) and maintained for another 2 days. The enriched myocytes were then subjected to hypoxia. The rats were handled according to the Guide for the Care and Use of Laboratory Animals published by the US National Institute of Health (NIH Publication No. 85-23, revised 2011). The study was reviewed and approved by the Institutional Animal Care and Use Committee of Shin Kong Wu Ho-Su Memorial Hospital.

\section{Hypoxia settings for cardiomyocyte culture}

Hypoxic conditions were achieved by adding medium pre-equilibrated with nitrogen gas to the cells prior to incubation in a Plexiglas chamber purged with watersaturated nitrogen gas by an oxygen controller (PROOX model 110; BioSpherix Ltd., Redfield, NY, USA). The partial pressure of oxygen $\left(p \mathrm{O}_{2}\right)$ of the culture medium under hypoxic condition was monitored using an $\mathrm{ISO}_{2}$ dissolved oxygen meter (World Precision Instruments, Inc., Sarasota, FL, USA). Measurements indicated that a steady state in the culture medium was maintained during experiments. Hypoxia culture media (BioSpherix C-chamber) was used with mixed air in and out controlled by a BioSpherix PROOX incubator. Hypoxia settings were as follows: i) $10 \% \mathrm{O}_{2}, 5 \% \mathrm{CO}_{2}$, and $85 \% \mathrm{~N}_{2}$; ii) $5 \%$ $\mathrm{O}_{2}, 5 \% \mathrm{CO}_{2}$, and $90 \% \mathrm{~N}_{2}$; and iii) $2.5 \% \mathrm{O}_{2}, 5 \% \mathrm{CO}_{2}$, and $92.5 \% \mathrm{~N}_{2}$. The use of a lower oxygen concentration (1\%) was also tested, but the cardiomyocytes did not survive under such severe hypoxia. Hypoxia was applied for 1, 2, 4 , and $6 \mathrm{~h}$ and for longer duration. The culture media were not changed during the duration of the experiment.

\section{Antibodies and reagents}

Polyclonal anti-UII, anti-UII-R, anti-collagen I, and anti-AngII antibodies were obtained from Santa Cruz Biotechnology. Different inhibitors were used to identify the signaling pathways involved in hypoxia-induced UII expression (Seta \& Millhorn 2004). Polyclonal antibodies against JNK and mAbs against phospho-JNK were obtained from Cell Signaling (Beverly, MA, USA). Mouse mAbs against p38 MAPK and ERK were purchased from BD Bioscience Pharmingen (San Diego, CA, USA). PD98059, SB203580, and SP600125 were purchased from Calbiochem (San Diego, CA, USA). Monoclonal anti- $\alpha$-tubulin antibody was obtained from Sigma. The role of JNK, p38 MAPK, and ERK in hypoxia-induced UII expression was determined by pretreatment of the myocytes with $25 \mu \mathrm{M}$ SP600125, $3 \mu \mathrm{M}$ SB203580, or $50 \mu \mathrm{M}$ PD98059 for $30 \mathrm{~min}$ before inducing hypoxia. SP600125 is a potent, cellpermeable, selective, and reversible inhibitor of JNK. SB203580 is a highly specific and cell-permeable inhibitor of p38 MAPK. PD98059 is a specific and potent inhibitor of the ERK pathway. AngII was purchased from Bachem AG (Torrance, CA, USA). To examine the effect of ARB (AngII type 1 receptor blocker), cardiomyocytes were treated with $100 \mathrm{nM}$ losartan (Merck \& Co., Inc.). $\mathrm{N}$-acetylL-cysteine (NAC; a free radical scavenger) and Dp44mT (2,2'-dipyridyl- $N, N$-dimethylsemicarbazone; an ROS generator) were purchased from Calbiochem and used at a concentration of $500 \mu \mathrm{M}$ and $30 \mathrm{nM}$ respectively.

\section{RNA isolation and real-time quantitative PCR}

Total cellular RNA was extracted from cardiomyocytes $\left(\sim 1.5 \times 10^{6}\right.$ cells) using TRI reagent (Molecular Research Center, Cincinnati, OH, USA) according to the manufacturer's instructions. One microgram of total RNA was reverse transcribed using M-MuLV reverse transcriptase (Finnzyme, Vantaa, Finland) in a total volume of $20 \mu$ l. The reverse transcriptase products were amplified with the DyNAmo HS SYBR Green qPCR Kit (Finnzyme) in the reaction mix containing DyNAmo SYBR Green Master Mix and primers. Primers were designed for detection of UII gene expression (forward, 5'-CGGACACTGGTGAAATG-3' and reverse, 5'-CCTGGTTCTCGCCAAA-3'). Gapdh gene expression was used as an internal control (forward, 5'-GAGAGGCTCTCTGTCGACTAC-3' and reverse, 5'-TAGTGTAGGTTGGGCGCTCAA-3'), and did not change under the above conditions.

\section{Western blot analysis}

Cardiomyocytes were washed in PBS and lysed with RIPA buffer containing $1 \%(\mathrm{v} / \mathrm{v})$ Nonidet P40, 0.5\% SDS, and protease inhibitor cocktail containing $10 \mu \mathrm{g} / \mathrm{ml}$ phenylmethylsulphonyl fluoride, $2 \mu \mathrm{g} / \mathrm{ml}$ leupeptin, $2 \mu \mathrm{g} / \mathrm{ml}$ pepstatin $\mathrm{A}$, and $2 \mu \mathrm{g} / \mathrm{ml}$ aprotinin. Cells were disrupted by intermittent sonication. After centrifugation, the amount of protein in the supernatant was measured using BSA as a standard. Cell lysates were then subjected to SDS/PAGE followed by western blotting. Antigen-antibody complexes were detected using with HRP-labeled rabbit anti-mouse immunoglobulin G (IgG) or goat anti-rabbit IgG and an ECL detection system (Pierce, Rockford, IL, USA).

Published by Bioscientifica Ltd 


\section{RNA interference}

Neonatal cardiomyocytes were transfected with $800 \mathrm{ng}$ JNK- and UII-annealed siRNA (Dharmacon, Lafayette, CO, USA). JNK or UII siRNAs are target-specific 20- to 25-nt siRNAs designed to knock down gene expression. The JNK sense and antisense siRNA sequences were 5'-CGUGGaUUUAUGGUCUGUGdTdT and 5'-CACAGACC-AUAAAUCCACGdTdT respectively. The UII sense and antisense of siRNA sequences were 5'-CACGGACACUGGUGAAAUGUU and 5'-PCAUUUCACCAGUGUCCGUGUU respectively. As a negative control, a nontargeting (control) siRNA (Dharmacon) was used. Neonatal cardiomyocytes were transfected with siRNA oligonucleotides, using Effectene transfection reagent according to the manufacturer's instructions (Qiagen). After incubation at $37^{\circ} \mathrm{C}$, cells were kept under hypoxia and analyzed by western blot.

\section{ROS assay and mitochondria isolation from cultured cardiomyocytes}

ROS production was measured using the cell-permeable probe $2^{\prime}, 7^{\prime}$-dichlorodihydrofluorescin diacetate, which passively diffuses into the cells where intracellular esterases cleave the acetate groups to form the impermeable $\mathrm{DCFH}_{2}$, which remains trapped within the cells (McLennan \& Degli Esposti 2000). After hypoxia treatment, cells were collected by trypsinization and resuspended in PBS medium. The ROS assay was performed according to the manufacturer's instructions (Invitrogen). Fluorescence microscopy was used to detect the green fluorescence. A mitochondrial isolation kit (Pierce) was used to isolate mitochondria from cultured cardiomyocytes as described previously (Zhang et al. 2010). Briefly, cultured cardiomyocyte pellets were gently lysed using a proprietary formulation that results in maximum yield of mitochondria with minimal damage to integrity.

\section{ELISA for Angll}

The level of AngII was measured using a quantitative sandwich enzyme immunoassay (SPI-BIO, Massy, France), using a specific anti-AngII antibody (Peninsula Laboratories, St Helens, Merseyside, UK), as described previously (Baker et al. 2004). Conditioned media from cultured cardiomyocytes under hypoxia and from control cells (normoxia) were collected for AngII measurement. The lower limit of detection of AngII was $0.5-1.5 \mathrm{pg} / \mathrm{ml}$. Both the intra-assay and the interassay coefficients of variation were $<10 \%$.

\section{Electrophoretic mobility shift assay}

Nuclear protein concentration from cultured myocytes was determined by the Bradford method following the manufacturer's recommendations (Bio-Rad). Consensus and control oligonucleotides (Research Biolabs, Singapore) were labeled by the polynucleotide kinase incorporation of $\left[\gamma^{-32} \mathrm{P}\right]$ ATP. The consensus oligonucleotide sequence of AP1 was 5'-CGCTTGATGACTCAGCCGGAA-3'. The AP1 mutant oligonucleotide sequence was 5'-CGCTTGATGACTTGGCCGGAA-3'. Electrophoretic mobility shift assay (EMSA) was performed as described previously (Chang et al. 2003). In each case, mutant or cold oligonucleotide, controls were used to compete with labeled sequences.

\section{Promoter activity assay}

A -664 to +44 bp rat UII promoter construct was generated as follows: rat genomic DNA was amplified with forward primer (CACAGCACTTTGCCAGGTTGA) and reverse primer (AGGAGTCCTACGAAGAGCAGG). The amplified product was digested with MluI and BglII restriction enzymes and ligated into pGL3-basic luciferase plasmid vector (Promega) digested with the same enzymes. The UII promoter contains the AP1-conserved sites (CA) at -621 to $-620 \mathrm{bp}$. To produce the mutant, the UII binding sites were mutated using a mutagenesis kit (Stratagene, La Jolla, CA, USA). Site-specific mutations were confirmed by DNA sequencing. Plasmids were transfected into cardiomyocytes using a low-pressure accelerated gene gun (Bioware, New Taipei City, Taiwan).

\section{Determination of protein synthesis}

Protein synthesis was examined by measuring ${ }^{3} \mathrm{H}$-proline incorporation into trichloroacetic acid-precipitated macromolecules. Cultured cardiomyocytes were divided into the following groups: i) the control group, in which cells were cultured in serum-free DMEM and ii) the hypoxia group, in which $2.5 \% \mathrm{O}_{2}$ was added to serumfree medium. Each experiment was repeated six times. Cardiomyocytes were first grown in DMEM with 10\% fetal bovine serum (FBS) and $200 \mathrm{mg} / \mathrm{l} \mathrm{L}$-glutamine and then seeded in 24-well plates at $1 \times 10^{5}$ cells/well in DMEM+ $10 \%$ FBS. After synchronization of cardiomyocytes, the medium was changed to DMEM without serum. Cardiomyocytes were incubated under hypoxia and exposed to ${ }^{3} \mathrm{H}$-proline at a concentration of $1 \mu \mathrm{Ci} /$ well for the last $1 \mathrm{~h}$ of the 4-h incubation period. After incubation, the cells

Published by Bioscientifica Ltd. 
were washed with ice-cold PBS and 10\% trichloroacetic acid. Acid-insoluble ${ }^{3} \mathrm{H}$-proline was collected on glass fiber filters (Whatman, Kent, UK) and measured using a liquid scintillation counter (LS 6500; Beckman, Fullerton, CA, USA).

\section{Statistical analysis}

The results are expressed as the mean \pm s.D. Statistical significance was evaluated using ANOVA followed by the Tukey-Kramer multiple comparisons test (GraphPad Software, Inc., San Diego, CA, USA). A value of $P<0.05$ was considered to denote statistical significance.

\section{Results}

\section{Hypoxia increases the expression of UII in cultured cardiomyocytes}

Different degrees of hypoxia (10, 5, and 2.5\%) for different periods of time $(1,2,4,6 \mathrm{~h}$, and longer) were used as described in the 'Materials and methods' section (Supplementary Fig. 1, see section on supplementary data given at the end of this article). UII expression was notably increased when cardiomyocytes were incubated in $2.5 \%$ $\mathrm{O}_{2}$ hypoxia conditions for $4 \mathrm{~h}$ compared with other conditions. Thus, these culture conditions were used for further analysis. There was no significant difference in $\mathrm{pH}$ between the different levels of hypoxia. In $2.5 \% \mathrm{O}_{2}$ hypoxia, UII and UII-R protein levels increased gradually and reached a peak after $4 \mathrm{~h}$ (Fig. 1A and B). UII mRNA expression also reached its maximal level after $2 \mathrm{~h}$ and then decreased gradually (Fig. 1C). UII protein expression was suppressed by UII siRNA (Supplementary Fig. 2).

\section{Hypoxia-induced UII protein expression in cardio- myocytes is mediated by ROS and the JNK pathway}

As shown in Fig. 2A and B, ROS production in cardiomyocytes was significantly increased by $2 \mathrm{~h}$ of hypoxia exposure. This effect was similar to that of the exogenous addition of Dp44mT. Similarly, ROS production from isolated mitochondria was significantly increased by hypoxia and Dp44mT treatment (Fig. 2C). Treatment with NAC for $30 \mathrm{~min}$ prior to subjecting the cardiomyocytes to hypoxia significantly blocked the hypoxia-induced ROS production. In the control group (normoxia), very few cardiomyocytes presented an increase in ROS production. In summary, hypoxia induces an increase in ROS production by cardiomyocytes and in mitochondria isolated from cardiomyocytes, suggesting

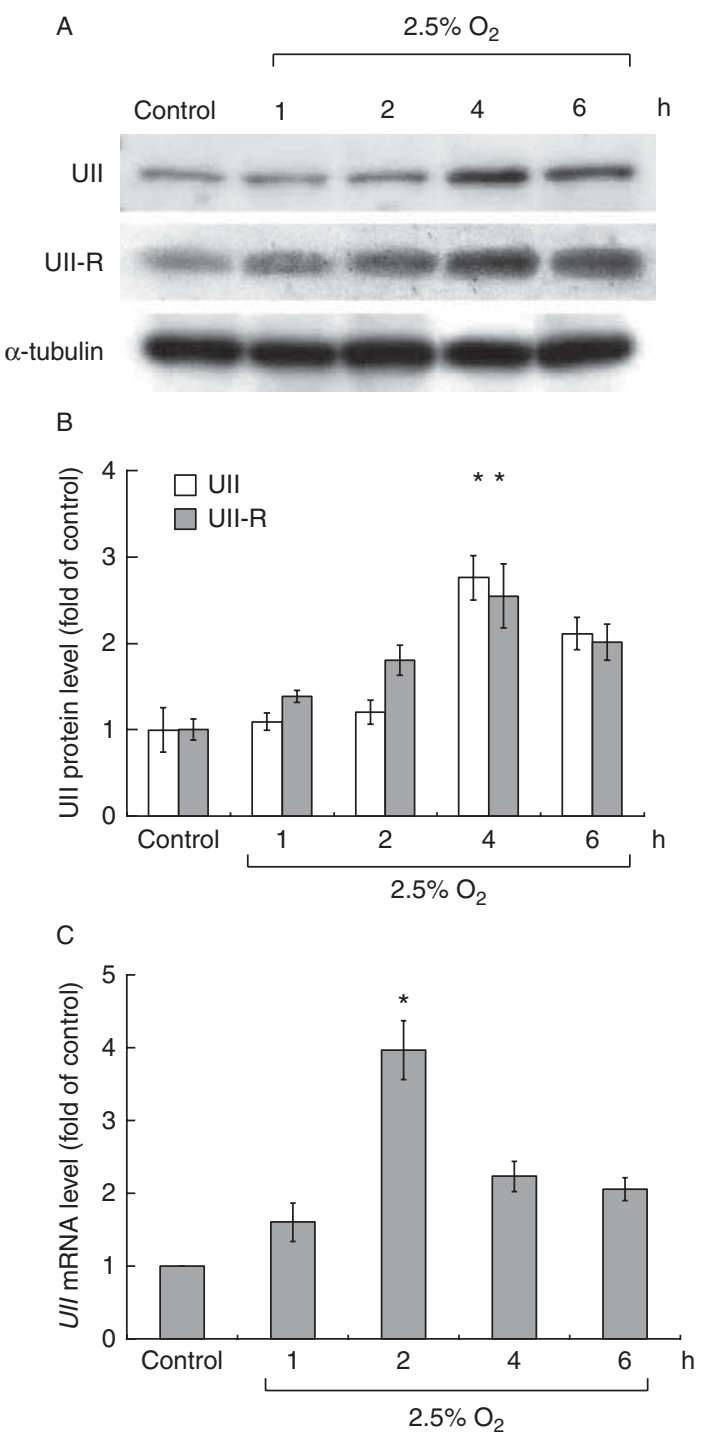

Figure 1

Effect of $2.5 \% \mathrm{O}_{2}$ hypoxia on UII expression in cardiomyocytes. (A and B) UII and UII-R protein levels increased, reaching a peak after $4 \mathrm{~h}$ of $2.5 \% \mathrm{O}_{2}$ hypoxia. Neonatal cardiomyocytes were subjected to hypoxia for 1-6 h. Total cell lysates were harvested and western blot was performed using anti-UII and anti-UII-R antibodies. $\alpha$-tubulin was used as a protein-loading control in each lane. ${ }^{*} P<0.01$ vs normoxia control $(n=3)$. (C) UII mRNA level reached a peak after $2 \mathrm{~h}$ of hypoxia and then declined. GAPDH was used as an internal control. ${ }^{*} P<0.01$ vs normoxia control $(n=3)$. UII, urotensin II; UII-R, UII receptor.

that ROS is produced by the mitochondria and that changes in mitochondria participated in ROS generation in our experiments.

To define the pathways involved in hypoxia-induced UII expression, different inhibitors were used. Hypoxiainduced UII expression was significantly inhibited by the JNK inhibitor (SP600125). This effect was confirmed using a JNK siRNA or NAC (Fig. 3A and B). The ERK and P38

Published by Bioscientifica Ltd. 
A

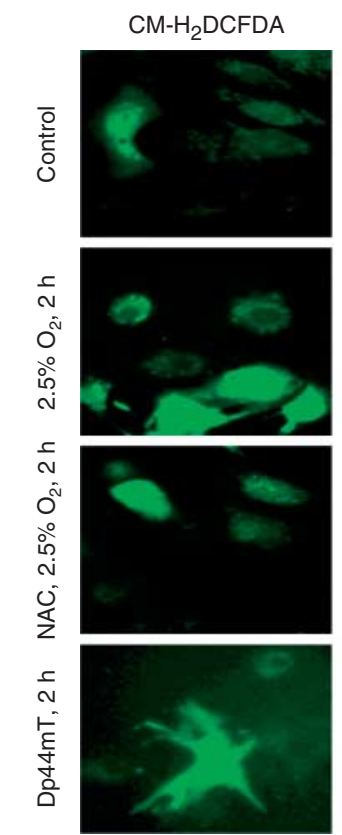

B

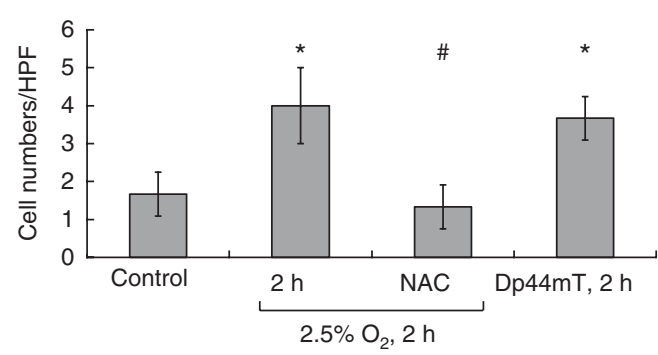

ROS assay

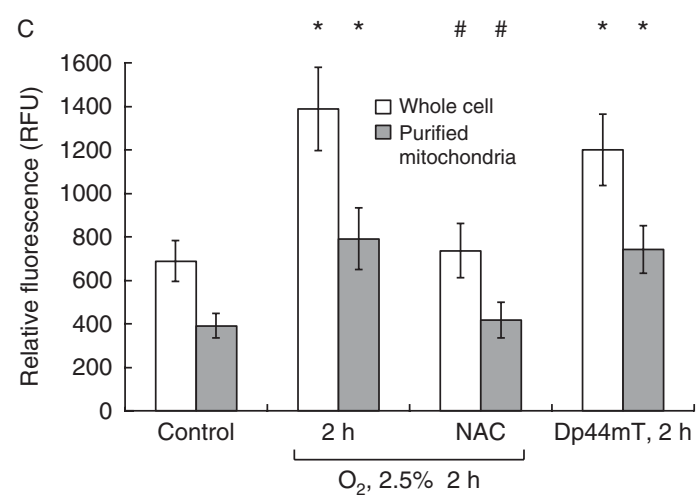

Figure 2

Hypoxia-induced UII protein expression in cardiomyocytes is mediated by ( $A$ and $B$ ) reactive oxygen species (ROS) assay, using a fluorescence microscope, indicated that hypoxia for $2 \mathrm{~h}$ increased ROS production similarly to that of the exogenous addition of ROS generator (Dp44mT). Treatment with NAC $(500 \mu \mathrm{M}) 30 \mathrm{~min}$ before hypoxia significantly blocked the induction. (C) Mitochondria isolation from cultured cardiomyocytes. Hypoxia and exogenously added Dp44mT (30 nM) significantly increased the ROS relative fluorescence unit (RFU) after $2 \mathrm{~h}$. Treatment with NAC for $30 \mathrm{~min}$ before hypoxia significantly blocked the RFU of ROS by hypoxia. ${ }^{*} P<0.01$ vs normoxia control. ${ }^{\#} P<0.01$ vs $2 \mathrm{~h}(n=3)$. inhibitors did not attenuate the UII protein expression induced by hypoxia. JNK protein phosphorylation increased to its maximal level after $2 \mathrm{~h}$ of $2.5 \% \mathrm{O}_{2}$ hypoxia and then declined gradually. SP600125, JNK siRNA, and NAC could effectively block the phosphorylation of JNK protein (Fig. 3C and D). Exogenously added Dp44mT under normoxia also increased UII expression, which was inhibited by JNK siRNA (Fig. 4B and C).

\section{Angll mediates the induction of UII by hypoxia in cultured cardiomyocytes}

Under $2.5 \% \mathrm{O}_{2}$ hypoxia, the AngII protein level increased and reached a peak after $2 \mathrm{~h}$ of incubation (earlier than UII and UII-R protein peak expression after $4 \mathrm{~h}$ of incubation) and then declined gradually (Fig. 4A). The UII protein level increased after $2.5 \% \mathrm{O}_{2}$ hypoxia but was suppressed by ARB (losartan: $100 \mathrm{nM}$ ) and AngII blocking antibodies (Fig. 4B and C). In addition, exogenous addition of AngII under normoxia also increased UII expression (Fig. 4B and $\mathrm{C})$.

Hypoxia increases the binding between the UII promoter and AP1 transcription factor and enhances genetic transcription activity of AP1 to UII promoter in cardiomyocytes

Under $2.5 \% \mathrm{O}_{2}$ hypoxia, EMSA showed increased binding activity between UII promoter and AP1 transcription factor. SP600125 and NAC inhibited the binding activity between UII promoter and AP1 transcription factor (Fig. 5A). This finding indicated that hypoxia in cardiomyocytes may increase the binding between UII promoter and AP1 transcription factor. Hypoxia-induced JNK phosphorylation and ROS may increase UII expression and UII/AP1 binding activity.

The luciferase reporter assay also showed (Fig. 5B and $C$ ) that hypoxia increased transcriptional activity of AP1 to UII promoter in cardiomyocytes. Mutation of the UII promoter inhibited this effect of hypoxia. Exogenously added AngII also increased the transcriptional activity of AP1 to UII promoter. SP600125, NAC, and losartan suppressed the transcriptional activity of the UII promoter in cardiomyocytes under hypoxia.

\section{Hypoxia modulates collagen I protein expression in cardiomyocytes}

As shown in Fig. 6, $4 \mathrm{~h}$ of hypoxia significantly increased collagen I protein expression in cardiomyocytes

Published by Bioscientifica Ltd. 
(Fig. 6A and B). SP600125, NAC, and UII siRNA effectively attenuated the collagen I protein expression induced by hypoxia (Fig. 6C and D). In addition, exogenous addition of AngII and UII under normoxia also increased collagen I protein expression in cardiomyocytes. Under normoxia, AngII-induced collagen I protein expression could also be effectively suppressed by UII siRNA (Fig. 6C and D).
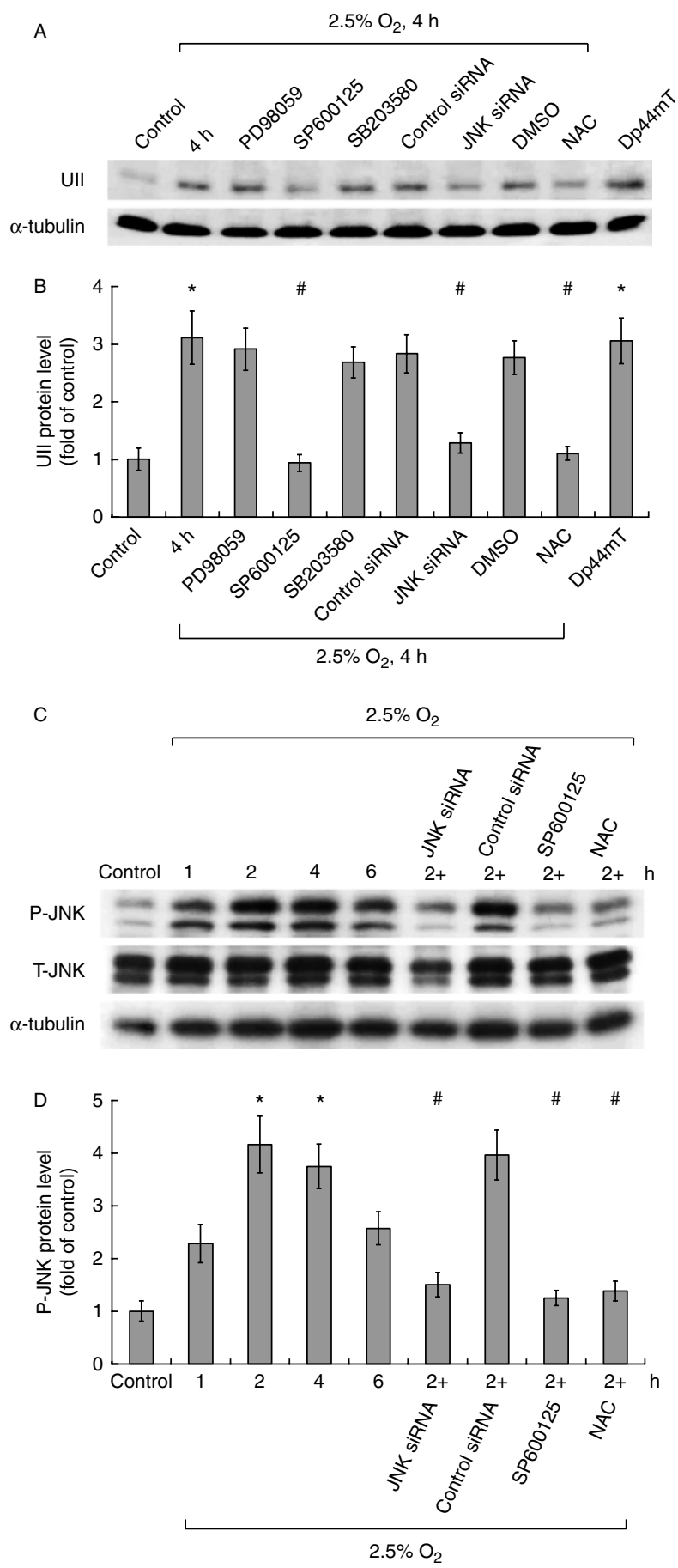

http://joe.endocrinology-journals.org DOI: $10.1530 / J O E-13-0261$
Hypoxia increases collagen I expression in the perinuclei, protein synthesis, and genetic transcription to induce cardiomyocyte hypertrophy

Under hypoxia, UII increased transcriptional activity in cardiomyocytes. Confocal microscopy (Supplementary Fig. 3, see section on supplementary data given at the end of this article) showed increased collagen I expression (green) in the perinuclei (blue) $4 \mathrm{~h}$ after hypoxia, which contributed to hypertrophic changes in cardiomyocytes. Ang II and UII also increased the expression of collagen I in the perinuclei of cardiomyocytes. Collagen I expression was suppressed by SP600125, NAC, and UII siRNA. Protein synthesis in cardiomyocytes was also evaluated by measuring ${ }^{3} \mathrm{H}$-proline incorporation into the cells. Results showed an increase in protein synthesis after $1-4 \mathrm{~h}$ of hypoxia, indicative of hypertrophic changes in cardiomyocytes (Fig. 7). Pretreatment with NAC, AngII antibody, losartan, UII siRNA, and SP600125 inhibited the protein synthesis induced by hypoxia. Exogenous addition of UII, AngII, and Dp44mT under normoxia also increased protein synthesis similarly to hypoxia.

\section{Discussion}

UII plays an important role in cardiac hypertrophy and cardiac fibrosis. Vasoactive effects of mammalian UII are dependent both on the species and on the regional vascular bed examined. Typical regional variability occurs in the rat in which vasoconstriction to UII is most robust in thoracic aorta proximal to the aortic arch and decreases gradually toward the distal peripheral arteries. Small peripheral arteries play a major role in regulating peripheral resistance and consequent blood pressure as well as workload on the heart (Ames et al. 1999).

\section{Figure 3}

The JNK pathway mediates hypoxia-induced UII expression in neonatal cardiomyocytes. (A and B) Hypoxia-induced UII expression was blocked by JNK inhibitor (SP600125), JNK siRNA, and NAC. Exogenous addition of Dp44mT (a ROS generator) under normoxia also increased UII expression. Neonatal cardiomyocytes were pretreated with an ERK pathway inhibitor (PD98059; $50 \mu \mathrm{M}$ ), a JNK inhibitor (SP600125; $25 \mu \mathrm{M}$ ), a p38 MAPK inhibitor (SB203580; $3 \mu \mathrm{M}), \mathrm{NAC}$, or JNK siRNA prior to hypoxia for $4 \mathrm{~h}$. The neonatal cardiomyocytes were then harvested and analyzed by western blotting using anti-Ull antibody. The results were normalized to $\alpha$-tubulin. ${ }^{*} P<0.01$ vs normoxia control. ${ }^{\#} P<0.01$ vs $4 \mathrm{~h}(n=3)$. (C and D) Phosphorylation of JNK mediated hypoxia-induced UII expression in neonatal cardiomyocytes, which was blocked by JNK inhibitor (SP600125), JNK siRNA, and NAC. Neonatal cardiomyocytes were subjected to normoxia or hypoxia for different durations in the presence or absence of inhibitors. Cell lysates were collected for western blot analysis, using antibody for total and phospho-JNK. T-JNK, total JNK; P-JNK, JNK phosphorylation. ${ }^{\star} P<0.01$ vs normoxia control. ${ }^{\#} P<0.01$ vs $2 \mathrm{~h}(n=3)$.

Published by Bioscientifica Ltd 
A

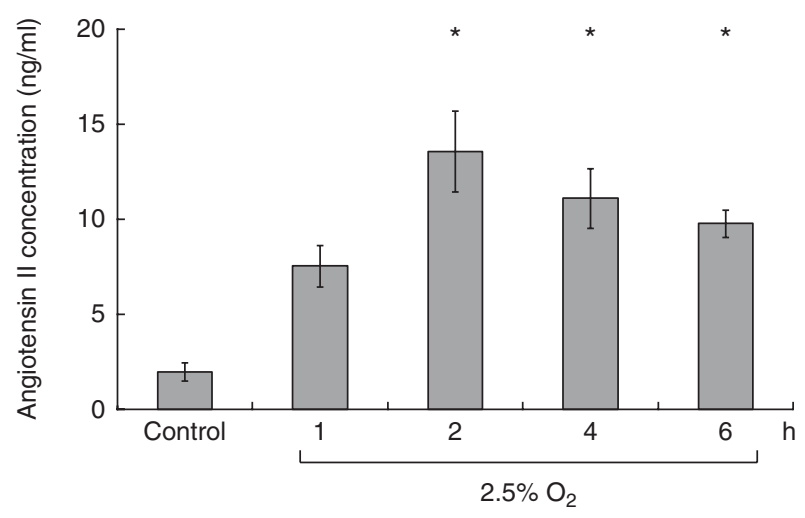

B
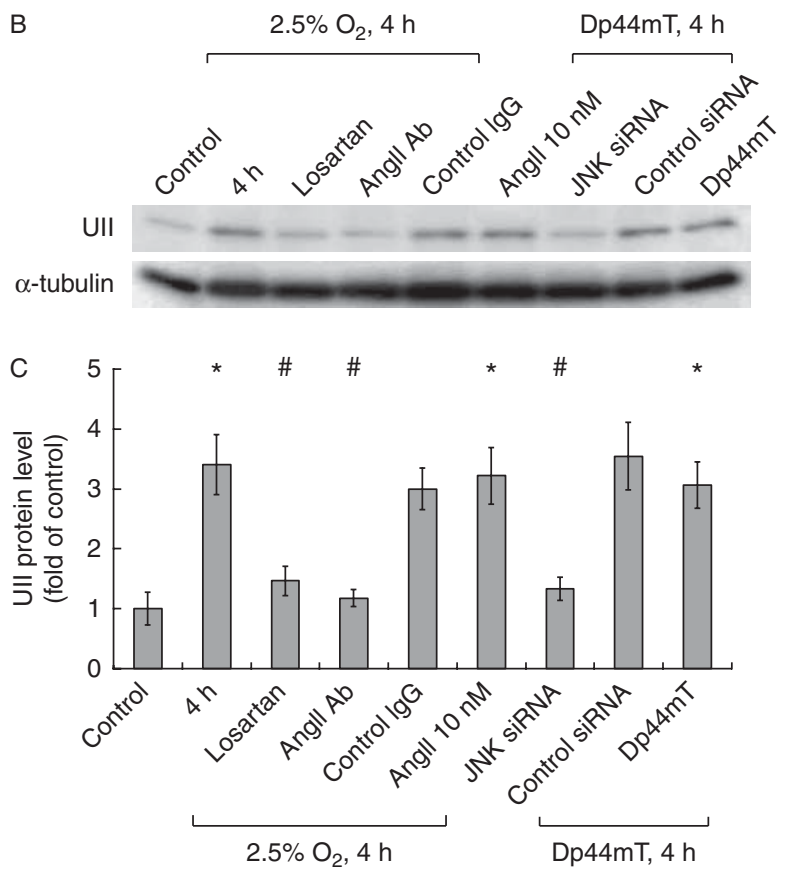

\section{Figure 4}

Angll mediates hypoxia-induced UII expression in neonatal cardiomyocytes. (A) Angll was measured in cell lysates and the culture medium by a quantitative, competitive ELISA using a specific anti-Angll antibody. $* P<0.01$ vs normoxia control. (B and C) Hypoxia-induced Ull expression was suppressed by Angll antibody and losartan. Exogenous addition of Dp44mT or Angll (under normoxia) also increased UII expression. UII expression induced by exogenous addition of Dp44mT was suppressed by JNK siRNA. Neonatal cardiomyocytes were subjected to normoxia or hypoxia for $4 \mathrm{~h}$ and total cell lysates were immunoblotted with anti-Ull antibody. $\alpha$-tubulin was used as a protein loading control in each lane. ${ }^{*} P<0.01$ vs normoxia control. ${ }^{\#} P<0.01$ vs $4 \mathrm{~h}(n=3)$.

UII-R activation is associated with multiple physiological actions such as vasoconstriction, vasodilation, osmoregulation, inhibition of insulin, and cell proliferation (Zhu et al. 2006, Ames et al. 2008). Similar to AngII (Chen et al. 2004) and ET-1 (Chen et al. 2005), UII-induced myocyte hypertrophy may contribute to cardiac remodeling and deterioration of cardiac function. Tzanidis et al. (2003) demonstrated the expression of both UII and UII-R within myocardial tissue, suggesting an important role for UII in cardiac pathophysiology. Zhou et al. (2003) reported UII-dependent hypertrophy in isolated cardiomyocyte cultures. Increased UII and UII mRNA as well as greater density of UII binding sites have been found in the myocardium and plasma of patients with congestive heart failure (Douglas et al. 2002, Gruson et al. 2006) and acute myocardial infarction (Khan et al. 2007), as well as in rats with diabetic cardiomyopathy (Dai et al. 2008). Bousette et al. (2006) reported that blockade of UII attenuated cardiac dysfunction in a rat model of coronary ligation. Furthermore, UII correlated significantly with ET-1 and brain natriuretic peptide, suggesting that UII may play a role in congestive heart failure worsening (Tang et al. 2010). UII may contribute to cardiac hypertrophy through upregulation of UII-R and inflammatory cytokines (Tzanidis et al. 2003).

Hypoxia is a commonly seen pathological phenomenon in cardiovascular diseases, including coronary artery disease, myocardial infarction, and heart failure. In cardiomyocytes, hypoxia produces stress, inducing the expression of specific cardiac-restricted genes. Tissue hypoxia is a feature of chronic inflammatory disease and may contribute to the development of oxidative stress and cardiomyocyte hypertrophy, as previously reported (Chiu et al. 2012). Recent studies have shown that UII stimulates NADPH oxidase, which generates ROS in pulmonary artery smooth muscle cells (Djordjevic et al. 2005). Human UII may worsen hypoxia-induced cardiac hypertrophy mainly through a vasoconstriction of the pulmonary artery and partly through the suppression of atrial natriuretic peptide secretion (Gao et al. 2010). Hypoxia stimulates UII-R upregulation and UII secretion both in vitro and in vivo (MacLean et al. 2000, Shyu et al. 2012). Finally, UII may act as an autocrine and/or paracrine hormone, playing an important role in the development of the ventricular hypertrophy induced by chronic hypoxia. Previous in vivo studies associated with pathologies generating ROS (heart failure, post-myocardial infarction, coronary artery ligation, ischemic-reperfusion injury, and diabetic cardiomyopathy) showed increased UII expression, indicating that administration of ROS in vivo may activate UII (Douglas et al. 2002, Ng et al. 2002, Bousette et al. 2006, Khan et al. 2007, Chen et al. 2008, Dai et al. 2008).

In this study, we identified some novel findings i) that hypoxia induces UII expression, causing cardiomyocyte hypertrophy; ii) that the JNK pathway specifically mediates hypoxia-induced UII expression in cardiomyocytes;

Published by Bioscientifica Ltd 
A

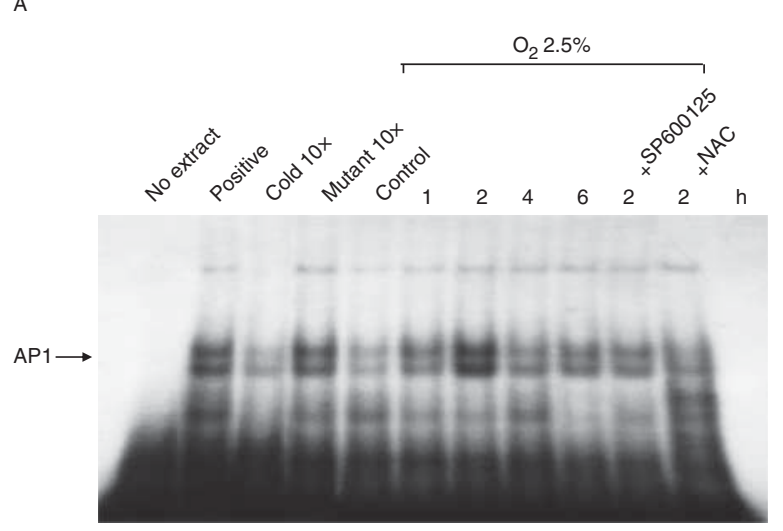

Figure 5

Binding activity between UII promoter and AP1 transcription factor and genetic transcription activity at the AP1-binding site of UII promoter increase in neonatal cardiomyocytes under hypoxia. (A) EMSA showed an increased in binding between UII promoter and AP1 transcription factor under in cardiomyocytes $2.5 \% \mathrm{O}_{2}$ hypoxia. The binding between UII promoter and AP1 transcription factor was suppressed by JNK inhibitor (SP600125) and NAC. (B and C) The luciferase reporter assay revealed that

iii) the effect of AngII and ROS on UII expression and genetic transcription in neonatal cardiomyocytes, causing cardiac hypertrophy; and iv) the relationship between AngII, ROS, UII, and collagen I expression in
B

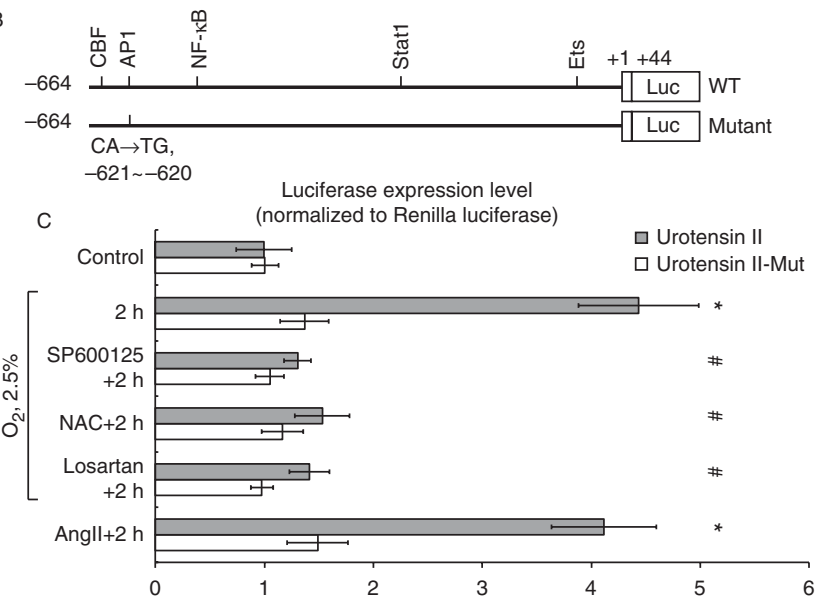

$2.5 \% \mathrm{O}_{2}$ hypoxia increased the transcriptional activity of AP-I to the UII promoter compared to the UII mutant. Transcriptional activity was suppressed by JNK inhibitor (SP600125), NAC, and losartan. Exogenous addition of Angll ( $10 \mathrm{nM}$ ) increased the transcriptional activity of neonatal cardiomyocytes similar to that of $2.5 \% \mathrm{O}_{2}$ hypoxia. ${ }^{*} P<0.01$ vs normoxia control. ${ }^{\#} P<0.01$ vs $2 \mathrm{~h}(n=3)$.

cardiomyocytes under hypoxia, which results in cardiac hypertrophy and fibrosis.

This study yielded results similar to our previous reports (Chiu et al. 2010, 2012, Shyu et al. 2012) regarding
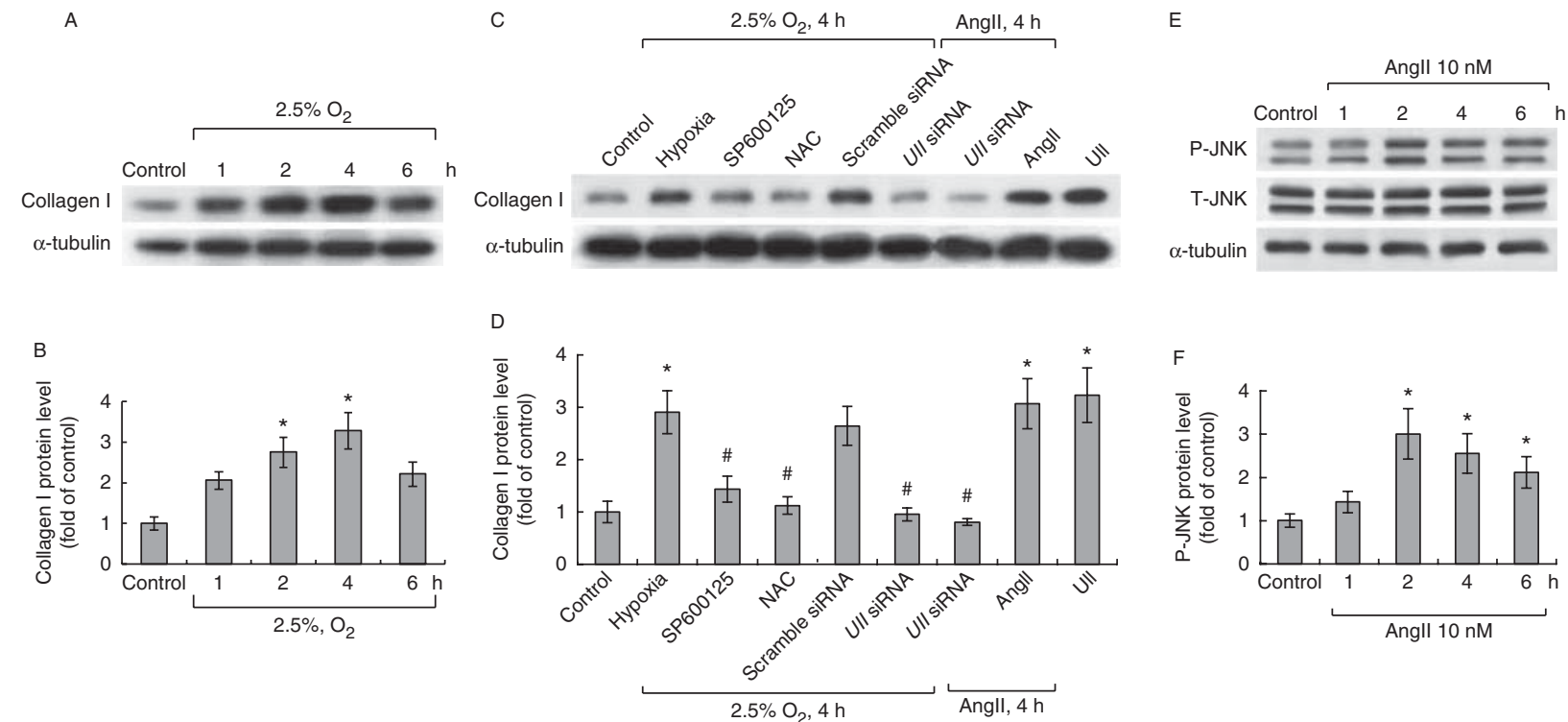

\section{Figure 6}

Hypoxia increases collagen I protein expression in cardiomyocytes. ( $A$ and $B$ ) Hypoxia increased collagen I expression, which reached a peak after $4 \mathrm{~h}$. (C and D) Hypoxia-induced collagen I expression was effectively suppressed by JNK inhibitor (SP600125), NAC, and UII siRNA. Exogenous addition of Angll or UII (under normoxia) also increased the expression of collagen I.
Collagen I expression induced by Angll was effectively suppressed by UII siRNA. (E and F) Exogenously added Angll increased JNK phosphorylation, which reached a peak after $2 \mathrm{~h}$. ${ }^{*} P<0.01$ vs normoxia control. ${ }^{\#} P<0.01$ vs hypoxia $(n=6)$ http://joe.endocrinology-journals.org DOI: 10.1530/JOE-13-0261
(C) 2014 Society for Endocrinology Printed in Great Britain
Published by Bioscientifica Ltd 


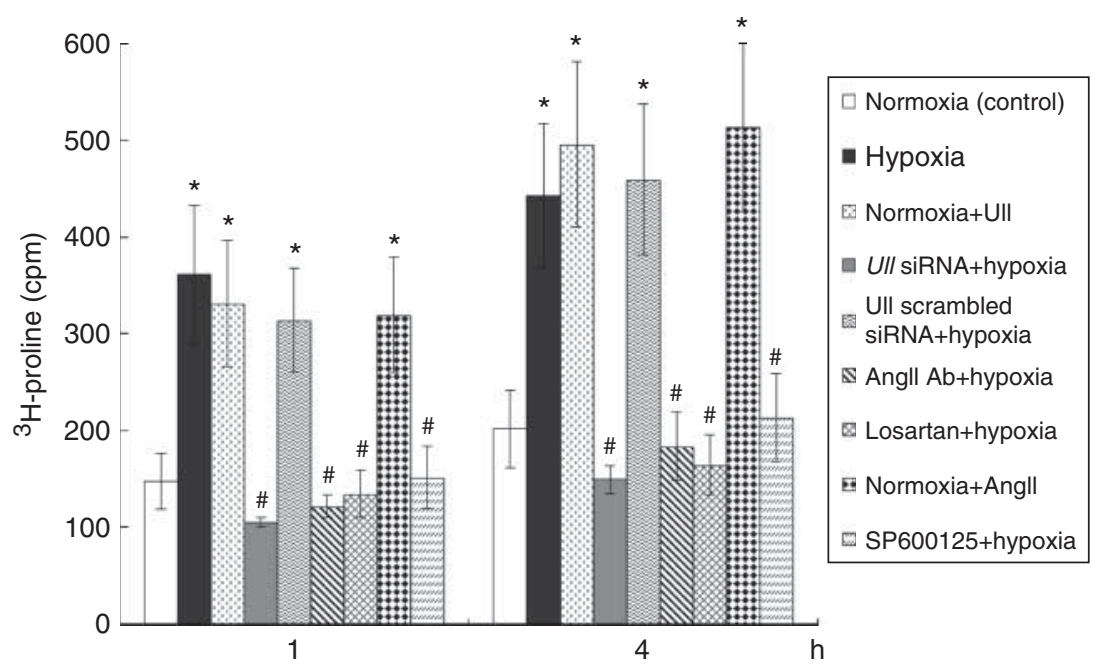

\section{Figure 7}

Neonatal cardiomyocytes protein synthesis increases after hypoxia. Incorporation of ${ }^{3} \mathrm{H}$-proline into neonatal cardiomyocytes increased after hypoxia and exogenous addition of UII, Angll, or Dp44mT (under normoxia) for $1-4 \mathrm{~h}$. Hypoxia-induced incorporation of ${ }^{3} \mathrm{H}$-proline into

the putative mechanism involved in the UII increase observed in cardiomyocytes subjected to $2.5 \%$ hypoxia. Mild hypoxia (10 or $5 \%$ ) did not induce significant oxidative stress to lead to an increase in UII expression. In addition, extreme hypoxia $(\leqq 1 \%)$ did not provide a suitable environment for cardiomyocytes to survive. Under $2.5 \% \mathrm{O}_{2}$ hypoxia, significant oxidative stress induced both ROS and hypoxic signaling (JNK) and activated UII expression. UII binds to a class of G proteincoupled receptor known as UII-R. UII and UII-R are highly expressed in the cardiovascular system and are upregulated in hypoxic myocardium. They also enhance foam cell formation, chemotaxis of inflammatory cells, as well as inotropic and hypertrophic effects on cardiac muscle.

Our study also identified the JNK pathway as the mediator of the hypoxia-induced UII expression in cardiomyocytes. The JNK pathway has been reported to mediate the oxidative stress induced by UII (Djordjevic et al. 2005). Moreover, hypoxia has been shown to stimulate JNK activation in cardiomyocytes. JNK mediates signals in response to cytokines and environmental stress, including oxidative stress. Previous studies indicated that JNK activation and ROS generation are immediate responses to low oxygen stress. Because the JNK pathway has been previously shown to be responsible for the hypoxic signaling, we successfully identified that either JNK siRNA or NAC could effectively attenuate hypoxia-induced JNK pathway activation in this study. neonatal cardiomyocytes was suppressed by UII siRNA, Angll blocking antibody, losartan, NAC, and JNK inhibitor (SP600125). * $P<0.01$ vs normoxia control. ${ }^{\#} P<0.01$ vs hypoxia $(n=6)$.

Previous studies have reported that UII expression and upregulation of UII-R promote cardiomyocyte hypertrophy via the p38 and ERK pathways in an EGFRdependent manner (Onan et al. 2004). However, in our study, the JNK pathway was the main pathway involved in the hypoxia-induced UII expression in cardiomyocytes.

With regard to JNK phosphorylation, it means activation of JNK pathway. As seen in previous and our studies, increases in JNK tyrosine phosphorylation and JNK activity occurred at an early hypoxic exposure time. In terms of the downstream significance of JNK activation by hypoxia, it is now well documented that hypoxia leads to the activation of AP1 that participate in the response of cells to hypoxia. Similarly, JNK phosphorylation enhanced oxidative phosphorylation and JNK pathway transduction to facilitate UII expression, and JNK inhibitor, JNK siRNA, and NAC repressed the expression of UII. Oxidative phosphorylation is intimately related to redox biology through control of the JNK signaling.

The relationship between AngII, ROS, and UII, as well as their regulatory effects on genetic transcription in cardiomyocytes, has not yet been defined. AngII has been shown to induce cardiac hypertrophy after hypoxia (Chiu et al. 2012). Hypoxia regulates the expression of UII in cardiomyocytes, and AngII acts as an upstream regulator of UII. Our study found that both hypoxia-induced AngII expression and exogenously added AngII-stimulated UII expression and genetic transcription in cardiomyocytes.

Published by Bioscientifica Ltd. 
These effects could be effectively inhibited by ARB. Infection with an adenovirus encoding the $\mathrm{AT}_{1}$ receptor was necessary to produce a reproducible hypertrophic response to AngII, strongly implicating receptor upregulation as the determinant for initiating hypertrophy. The interaction between AngII and UII has been shown to increase myocardial dispensability (Fontes-Sousa et al. 2009) and vasoconstriction (Wang et al. 2007). Previous reports also showed that, with the addition of AngII, the myocardial UII/UII-R system was upregulated in isoproterenol-treated rats, indicating that the UII/UII-R system is a newly identified regulating system involved in cardiac hypertrophy (Zhang et al. 2007). In this study, we demonstrated that hypoxia increased the secretion of AngII from cardiomyocytes and that the secreted AngII increased UII expression, resulting in cardiac hypertrophy.

Our data also showed that ROS is involved in cardiomyocyte hypertrophy induced by UII. In fact, hypoxia-induced UII expression, UII promoter and AP1 binding, UII-related genetic transcription in cardiomyocytes, and cardiomyocyte hypertrophy could be effectively suppressed by NAC. Hypoxia has been shown to stimulate oxidative stress and increase ROS formation with subsequent cardiomyocyte hypertrophy (Chiu et al. 2012). UII has also been shown to induce ROS and cardiomyocyte hypertrophy (Liu et al. 2009). Hypoxic signaling (JNK) modulated by ROS from the mitochondrion to the nucleus controls and promotes cardiomyocyte hypertrophy. Thus, ROS may be a second messenger mediating the effects of growth-promoting neurohumoral agonists and intracellular signaling pathways. $2.5 \%$ hypoxia represents a condition of significant oxidative stress associated with subsequent elevation of ROS. Mitochondria have long been considered a likely site of oxygen sensing, and the electron transport chain acts as an $\mathrm{O}_{2}$ sensor by releasing ROS in response to hypoxia. The ROS released during hypoxia act as signaling agents that trigger diverse functional responses, including activation of downstream transcription factor (AP1) and hypoxic signaling (JNK). The primary site of ROS production during hypoxia appears to be complex III in the electron transport chain in mitochondria. $\mathrm{O}_{2}$-free radical is generated in the mitochondria and requires coupled electron transport, ROS generation, and calcium flux. So, ROS is a product of mitochondria and mitochondrial ROS signals initiate the activation of JNK (Laderoute \& Webster 1997, Dougherty et al. 2004, Guzy \& Schumacker 2006).

In different cell types, different MAPK pathways may be involved in UII genetic transcription. Our study shows that AP1, a downstream target of JNK, plays a role in the transcriptional regulation of UII. The gel shift assay showed that UII promoter-DNA binding activity increased after hypoxia. This effect was abolished by the use of a UIImutant plasmid, SP600125, and ARB. In cardiomyocytes, UII-related genetic transcription occurs through AP1 binding to the UII promoter. The promoter activity assay confirmed the regulation of UII expression by AP1. In fact, the effects of hypoxia and AngII stimulation on UII promoter activity were abolished when the AP1 binding site was mutated. So, the regulatory DNA in UII promoter may participate in the transcriptional activity.

Hypoxia is a stimulus to collagen synthesis in cardiomyocytes. This study demonstrated that hypoxia increased collagen I expression and the presence of collagen I in the nuclei. This effect was effectively inhibited by NAC, JNK inhibitor, and UII siRNA, indicating a relationship between AngII, ROS, UII, and collagen I. In addition, UII or AngII, added exogenously, increased collagen I expression. AngII-related collagen I expression was also effectively inhibited by UII siRNA. Previous studies indicated that UII has effects on myocardial protein synthesis and was documented by increased ${ }^{3} \mathrm{H}$-proline into neonatal cardiomyocytes and myosin

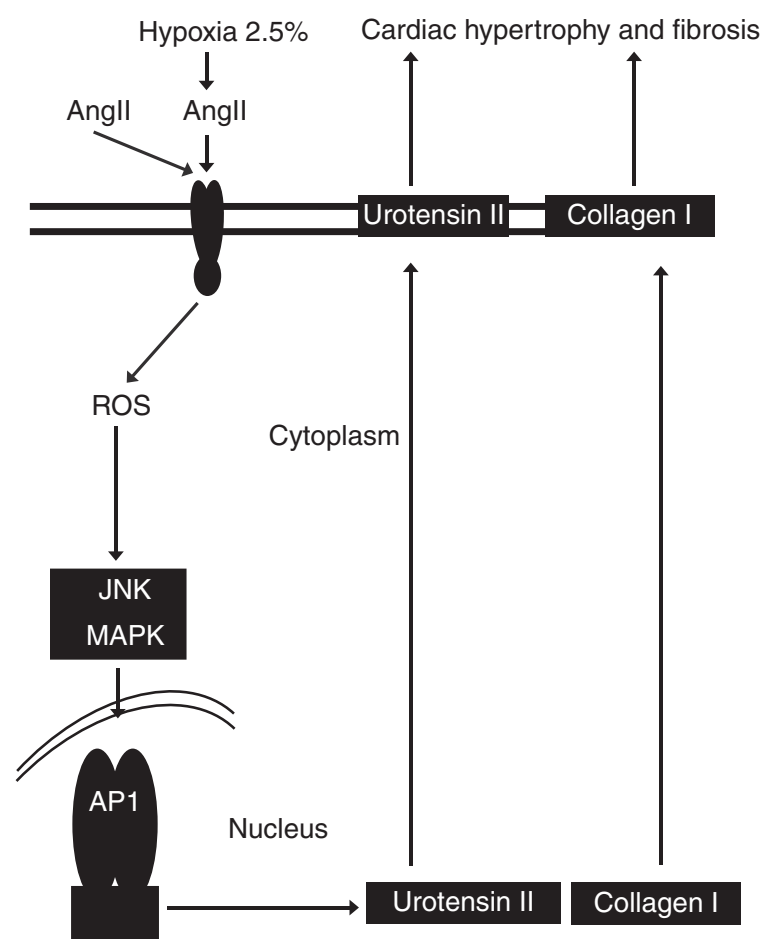

Figure 8

Schematic representation of the Angll/ROS/JNK pathway involved in the hypoxia-induced induction of UII expression leading to cardiomyocyte hypertrophy through increased transcriptional activity. 
expression (Tzanidis et al. 2003). In our study, UII also increased protein synthesis by increased incorporation of ${ }^{3} \mathrm{H}$-proline into neonatal cardiomyocytes. In conclusion, UII, AngII, and ROS mediated the expression of collagen I in cardiomyocytes subjected to hypoxia, resulting in cardiac fibrosis in addition to cardiac hypertrophy. The role of UII in the development of cardiac fibrosis results from its ability to increase collagen protein synthesis and secretion in the extracellular matrix. AngII has been shown to induce the secretion of profibrotic factors such as syndecan, transforming growth factor- $\beta 1$, and connective tissue growth factor in cardiac fibroblasts. In our study, exogenous AngII stimulation increased UII expression, JNK protein phosphorylation, and collagen I protein expression. These findings indicate that UII is a mediator of AngII-induced cardiac fibrosis. Previous studies indicated that other stress factors, including ischemic cardiomyopathy, postmyocardial infarction, heart failure, ischemic-reperfusion injury, and pressure overload to myocardium also induce UII-related collagen expression (Douglas et al. 2002, Ng et al. 2002, Tzanidis et al. 2003, Bousette et al. 2006, Chen et al. 2008).

With regard to medical treatment for UII-related cardiac diseases, vasoconstrictor effect of UII results in cardiac hypertrophy, hypertension, and heart failure. Administration of vasodilators, including ARBs, calcium channel blockers, or UII antagonists, may reverse cardiac hypertrophy and fibrosis, heart failure, and hypertension (Bousette et al. 2006, Gao et al. 2010, Bai et al. 2011).

In conclusion, hypoxia in cultured rat neonatal cardiomyocytes induces the expression of AngII and ROS. Ang II, ROS, and the JNK pathway mediate the induction of UII expression with subsequent cardiomyocyte hypertrophy through increased transcriptional activity in cardiomyocytes. Cardiomyocyte hypertrophy after hypoxia can be identified by increased protein synthesis and hypertrophic changes in cardiomyocytes. Hypoxia-induced AngII expression has similar effects to that of exogenously added AngII and may increase both UII expression and transcriptional activity in cardiomyocytes. Cardiomyocyte hypertrophy can be prevented by ARB, which represses the effect of AngII and UII. Thus, UII may be a potential therapeutic target for the treatment of ischemic heart disease with the aim of preventing cardiac hypertrophy and cardiac fibrosis (Fig. 8).

\section{Supplementary data}

This is linked to the online version of the paper at http://dx.doi.org/10.1530/ JOE-13-0261.

http://joe.endocrinology-journals.org DOI: 10.1530/JOE-13-0261

(c) 2014 Society for Endocrinology Printed in Great Britain

\section{Declaration of interest}

The authors declare that there is no conflict of interest that could be perceived as prejudicing the impartiality of the research reported.

\section{Funding}

The study was sponsored in part by the Shin Kong Wu Ho-Su Memorial Hospital.

\section{References}

Ames RS, Sarau HM, Chambers JK, Willette RN, Aiyar NV, Romanic AM, Louden CS, Foley JJ, Sauermelch CF, Coatney RW et al. 1999 Human urotensin-II is a potent vasoconstrictor and agonist for the orphan receptor GPR14. Nature 401 282-286. (doi:10.1038/45809)

Ames RS, Sarau HM, Chambers JK, Willette RN, Aiyar NV, Romanic AM, Tolle M \& van der Giet M 2008 Cardiorenovascular effects of urotensin II and the relevance of the UT receptor. Peptides 29 743-763. (doi:10.1016/j.peptides.2007.08.029)

Bai XY, Liu XC, Yang Q, Tang XD \& He GW 2011 The interaction between human urotensin II and vasodilator agents in human internal mammary artery with possible clinical implications. Annals of Thoracic Surgery 92 610-616. (doi:10.1016/j.athoracsur.2011.03.094)

Baker KM, Chernin MI, Schreiber T, Sanghi S, Haiderzaidi S, Booz GW, Dostal DE \& Kumar R 2004 Evidence of a novel intracrine mechanism in angiotensin II-induced cardiac hypertrophy. Regulatory Peptides 120 5-13. (doi:10.1016/j.regpep.2004.04.004)

Bousette N \& Giaid A 2006 Urotensin-II and cardiovascular diseases. Current Hypertension Reports 8 479-483. (doi:10.1007/s11906-006-0026-7)

Bousette N, Hu F, Ohlstein EH, Dhanak D, Douglas SA \& Giaid A 2006 Urotensin-II blockade with SB-611812 attenuates cardiac dysfunction in a rat model of coronary artery ligation. Journal of Molecular and Cellular Cardiology 41 285-295. (doi:10.1016/j.yjmcc.2006.05.008)

Chang H, Shyu KG, Wang BW \& Kuan P 2003 Regulation of hypoxiainducible factor $1-\alpha$ by cyclical mechanical stretch in rat vascular smooth muscle cells. Clinical Science 105 447-456. (doi:10.1042/ CS20030088)

Chen K, Mehta JL, Li D, Joseph L \& Joseph J 2004 Transforming growth factor $\beta$ receptor endoglin is expressed in cardiac fibroblasts and modulates profibrogenic actions of angiotensin II. Circulation Research 95 1167-1173. (doi:10.1161/01.RES.0000150369.68826.2f)

Chen SC, Cheng JJ, Hsieh MH, Chu YL, Kao PF, Cheng TH \& Chan P 2005 Molecular mechanism of the inhibitory effect of trilinolein on endothelin-1-induced hypertrophy of cultured neonatal rat cardiomyocytes. Planta Medica 71 525-529. (doi:10.1055/s-2005-864153)

Chen YL, Liu JC, Loh SH, Chen CH, Hong CY, Chen JJ \& Cheng TH 2008 Involvement of reactive oxygen species in urotensin II-induced proliferation of cardiac fibroblasts. European Journal of Pharmacology 593 24-29. (doi:10.1016/j.ejphar.2008.07.025)

Chiu CZ, Wang BW, Chun TH \& Shyu KG 2010 Angiotensin II the ERK pathway mediate the induction of myocardin by hypoxia in cultured rat cardiomyocytes. Clinical Science 119 273-282. (doi:10.1042/ CS20100084)

Chiu CZ, Wang BW \& Shyu KG 2012 Use of atorvastatin to inhibit hypoxiainduced myocardin expression. European Journal of Clinical Investigation 42 564-571. (doi:10.1111/j.1365-2362.2011.02628.x)

Dai HY, Guo XG, Ge ZM, Li ZH, Yu XJ, Tang MX \& Zhang Y 2008 Elevated expression of urotensin II and its receptor in diabetic cardiomyopathy. Journal of Diabetes and its Complications 22 137-143. (doi:10.1016/ j.jdiacomp.2006.10.008)

Djordjevic T, BelAiba RS, Boncello S, Pfeilschifter J, Hess J \& Gorlach A 2005 Human urotensin II is a novel activator of NADPH oxidase in human pulmonary artery smooth muscle cells. Arteriosclerosis, Thrombosis, and

Published by Bioscientifica Ltd. 
Vascular Biology 25 519-525. (doi:10.1161/01.ATV.0000154279. 98244.eb)

Dougherty CJ, Kubasiak LA, Freazier DP, Li H, Xiong WC, Bishopric NH \& Webster KA 2004 Mitochondrial signals initiate the activation of c-Jun $N$-terminal kinase (JNK) by hypoxia-reoxygenation. FASEB Journal 181060-181070. (doi:10.1096/fj.04-1505com July 2004)

Douglas SA, Tayara L, Ohlstein EH, Halawa N \& Giaid A 2002 Congestive heart failure and expression of myocardial urotensin II. Lancet 359 1990-1997. (doi:10.1016/S0140-6736(02)08831-1)

Fontes-Sousa AP, Pires AL, Monteiro-Cardoso VF \& Leite-Moreira AF 2009 Urotensin II-induced increase in myocardial distensibility is modulated by angiotensin II and endothelin-1. Physiological Research 58 653-660.

Gao S, Oh YB, Shah A, Park WH, Chung MJ, Lee YH \& Kim SH 2010 Urotensin II receptor antagonist attenuates monocrotaline-induced cardiac hypertrophy in rats. American Journal of Physiology. Heart and Circulatory Physiology 299 H1782-H1789. (doi:10.1152/ajpheart. 00438.2010)

Gould PS, Gu M, Liao J, Ahmad S, Cudmore MJ, Ahmed A \& Vatish M 2010 Upregulation of urotensin II receptor in preeclampsia causes in vitro: placental release of soluble vascular endothelial growth factor receptor 1 in hypoxia. Hypertension 56 172-178. (doi:10.1161/ HYPERTENSIONAHA.110.152074)

Gruson D, Rousseau MF, Ahn SA, van Linden F \& Ketelslegers JM 2006 Circulating urotensin II levels in moderate to severe congestive heart failure: its relations with myocardial function and well established neurohormonal markers. Peptides 27 1527-1531. (doi:10.1016/ j.peptides.2005.11.019)

Guzy RD \& Schumacker PR 2006 Oxygen sensing by mitochondria at complex III: the paradox of increased reactive oxygen species during hypoxia. Experimental Physiology 91 807-819. (doi:10.1113/expphysiol. 2006.033506)

Huang H, Gong YS, Fan XF, Hu LG, Luo JF \& Wu XM 2006 Expression of urotensin II and its receptor on right ventricle in rats of pulmonary hypertension. Zhongguo Ying Yong Sheng Li Xue Za Zhi 22 81-84.

Inamoto S, Hayashi T, Tazawa N, Mori T, Yamashita C, Nakano D, Sohmiya K, Okada Y, Kitaura Y \& Matsumura Y 2006 Angiotensin-II receptor blocker exerts cardioprotection in diabetic rats exposed to hypoxia. Circulation Journal 70 787-792. (doi:10.1253/circj.70.787)

Khan SQ, Bhandari SS, Quinn P, Davies JE \& Ng LL 2007 Urotensin II is raised in acute myocardial infarction and low levels predict risk of adverse clinical outcome in humans. International Journal of Cardiology 117 323-328. (doi:10.1016/j.ijcard.2006.05.016)

Kontaraji JE, Parthenakis FI, Patrianakos AP, Karalis IK \& Vardas PE 2007 Altered expression of early marker genes in circulating cells of patients with hypertrophic cardiomyopathy. Cardiovascular Pathology 16 329-335. (doi:10.1016/j.carpath.2007.04.004)

Laderoute KR \& Webster KA 1997 Hypoxia/reoxygenation stimulates Jun kinase activity through redox signaling in cardiac myocytes. Circulation Research 336

Lamarre NS \& Tallarida RJ 2008 A quantitative study to assess synergistic interactions between urotensin II and angiotensin II. European Journal of Pharmacology 586 350-351. (doi:10.1016/j.ejphar. 2008.02.071)

Li J, Wang J, Russell FD \& Molenaar P 2005 Activation of calcineurin in human failing heart ventricle by endothelin-1, angiotensin II and urotensin II. British Journal of Pharmacology 145 432-440. (doi:10.1038/ sj.bjp.0706217)

Liu JC, Chen CH, Chen JJ \& Cheng TH 2009 Urotensin II induces rat cardiomyocyte hypertrophy via the transient oxidization of src homology 2-containing tyrosine phosphatase and transactivation of epidermal growth factor receptor. Molecular Pharmacology 76 1186-1195. (doi:10.1124/mol.109.058297)

MacLean MR, Alexander D, Stirrat A, Gallagher M, Douglas SA, Ohlstein EH, Morecroft I \& Polland K 2000 Contractile response to human urotensinII in rat and human pulmonary arteries: effect of endothelial factors and chronic hypoxia in the rat. British Journal of Pharmacology 130 201-204. (doi:10.1038/sj.bjp.0703314)

McLennan HR \& Degli Esposti M 2000 The contribution of mitochondrial respiratory complexes to the production of reactive oxygen species. Journal of Bioenergetics and Biomembranes 32 153-162. (doi:10.1023/ A:1005507913372)

Ng LL, Loke I, O’Brien R, Squire IB \& Davies JE 2002 Plasma urotensin in human systolic heart failure. Circulation 106 2877-2880. (doi:10.1161/ 01.CIR.0000044388.19119.02)

Ni YG, Berenji K, Wang N, Oh M, Sachan N, Dey A, Cheng J, Lu G, Morris DJ, Castrillon DH et al. 2006 Foxo transcription factors blunt cardiac hypertrophy by inhibiting calcineurin signaling. Circulation 114 1159-1168. (doi:10.1161/CIRCULATIONAHA.106.637124)

Onan D, Pipolo L, Yang E, Hannan RD \& Thomas WG 2004 Urotensin II promotes hypertrophy of cardiac myocytes via mitogen-activated protein kinases. Molecular Endocrinology 18 2344-2354. (doi:10.1210/ me.2003-0309)

Pakala R 2008 Role of urotensin II in atherosclerotic cardiovascular diseases. Cardiovascular Revascularization Medicine 9 166-178. (doi:10.1016/j.carrev.2008.02.001)

Papadopoulos P, Bousette N \& Giaid A 2008 Urotensin-II and cardiovascular remodeling. Peptides 29 764-769. (doi:10.1016/j.peptides. 2007.09.012)

Prosser HC, Forster ME, Richards AM \& Pemberton CJ 2008 Urotensin II and urotensin II-related peptide (URP) in cardiac ischemia-reperfusion injury. Peptides 29 770-777. (doi:10.1016/j.peptides.2007.08.013)

Segain JP, Rolli-Derkinderen M, Gervois N, de la Bletiere DR, Loirand G \& Pacaud P 2007 Urotensin II is a new chemotactic factor for UT receptorexpressing monocytes. Journal of Immunology 1799019.

Seta KA \& Millhorn DE 2004 Functional genomics approach to hypoxia signaling. Journal of Applied Physiology 96 765-773. (doi:10.1152/ japplphysiol.00836.2003)

Shyu KG, Chen CC, Wang BW \& Kuan P 2001 Angiotensin II receptor antagonist blocks the expression of connexin 43 induced by cyclical mechanical stretch in cultured neonatal rat cardiac myocytes. Journal of Molecular and Cellular Cardiology 33 691-698. (doi:10.1006/jmcc.2000. 1333)

Shyu KG, Wang BW, Chen WJ, Kuan P \& Lin CM 2012 Angiotensin II mediates urotensin II expression by hypoxia in cultured cardiac fibroblast. European Journal of Clinical Investigation 42 16-64. (doi:10.1111/j.1365-2362.2011.02549.x)

Song N, Ding W, Chu S, Zhao J, Dong X, Di B \& Tang C 2012 Urotensin II stimulates vascular endothelial growth factor secretion from adventitial fibroblasts in synergy with angiotensin II. Circulation Journal 76 1267-1273. (doi:10.1253/circj.CJ-11-0870)

Tang WH, Shrestha K, Martin MG, Borowski AG, Jasper S, Yandle TG, Richards AM, Klein AL \& Troughton RW 2010 Clinical significance of endogenous vasoactive neurohormones in chronic systolic heart failure. Journal of Cardiac Failure 16 635-640. (doi:10.1016/j.cardfail. 2010.03.011)

Tolle M \& van der Giet M 2008 Cardiorenovascular effects of urotensin II and the relevance of the UT receptor. Peptides 29 743-763. (doi:10.1016/j.peptides.2007.08.029)

Tzanidis A, Hannan RD, Thomas WG, Onan D, Autelitano DJ, See F, Kelly DJ, Gilbert RE \& Krum H 2003 Direct actions of urotensin II on the heart: implications for cardiac fibrosis and hypertrophy. Circulation Research 93 246-253. (doi:10.1161/01.RES.0000084382. 64418.BC)

Wang YX, Ding YJ, Zhu YZ, Shi Y, Yao T \& Zhu YC 2007 Role of PKC in the novel synergistic action of urotensin II and angiotensin II and in urotensin II-induced vasoconstriction. American Journal of Physiology. Heart and Circulatory Physiology 292 H348-H359. (doi:10.1152/ajpheart. 00512.2006)

Yamashita C, Hayashi T, Mori T, Tazawa N, Kwak CJ, Nakano D, Sohmiya K, Okada Y, Kitaura Y \& Matsumura Y 2007 Angiotensin II receptor blocker reduces oxidative stress and attenuates 
hypoxia-induced left ventricular remodeling in apolipoprotein Eknockout mice. Hypertension Research 30 1219-1230. (doi:10.1291/ hypres.30.1219)

Zhang Y, Li J, Cao J, Chen J, Yang J, Zhang Z, Du J \& Tang C 2002 Effect of chronic hypoxia on contents of urotensin II and its functional receptors in rat myocardium. Heart and Vessels 16 64-68. (doi:10.1007/ s380-002-8319-2)

Zhang YG, Li YG, Liu BG, Wei RH, Wang DM, Tan XR, Bu DF, Pang YZ \& Tang CS 2007 Urotensin II accelerates cardiac fibrosis and hypertrophy of rats induced by isoproterenol. Acta Pharmacologica Sinica 28 36-43. (doi:10.1111/j.1745-7254.2007.00485.x)
Zhang Q, Raoof M, Chen Y, Sumi Y, Sursal T, Junger W, Brohi K, Itagaki K \& Hauser CJ 2010 Circulating mitochondrial DAMPs cause inflammatory responses to injury. Nature 464 104-107. (doi:10.1038/ nature08780)

Zhou P, Wu SY, Yu CF, Wang H, Tang CS, Lin L \& Yuan WJ 2003 Effects of urotensin II on isolated rat hearts under normal perfusion and ischemia reperfusion. Sheng Li Xue Bao: Acta Physiologica Sinica 55 442-448.

Zhu YC, Zhu YZ \& Moore PK 2006 The role of urotensin II in cardiovascular and renal physiology and diseases. British Journal of Pharmacology 148 884-901. (doi:10.1038/sj.bjp.0706800)

Received in final form 17 December 2013

Accepted 19 December 2013 (c) 2014 Society for Endocrinology Printed in Great Britain
Published by Bioscientifica Ltd. 